\title{
Improving Educational Equity in Romania
}

Romania has made significant progress in recent decades to modernise its education system and improve student learning outcomes. However, while the system enables some students to excel, too many progress through school without mastering basic competencies and a large share leave education before completing upper secondary education (Kitchen et al., 2017 [1]; Eurostat, 2019[2]). In 2016, the Educated Romania project began a multi-year national consultation led by the President of Romania, Klaus lohannis, to discuss key challenges for education in the country and identify objectives for 2030. The Educated Romania report puts forward a set of goals to increase access to quality education for all social groups, and in particular students from disadvantaged and under-represented groups. The report recommends that Romania:

- Improve access to high-quality education for all children (also see policy brief on early childhood education and care).

- Help struggling students early on in their education career.

- Help motivate students by creating a nurturing environment and holding high expectations for all students, with support targeted to those who are struggling.

- Distribute resources more equitably across schools and encourage social diversity.

- Give schools more freedom to decide what to teach and how to assess student progress.

- Involve parents, local communities, and offer special programmes to support children with vulnerable backgrounds, including students in rural areas, those from socio-economically disadvantaged families and those with disabilities.

The mission of the Structural Reform Support Service (SRSS) of the European Commission is to provide support for the preparation and implementation of growth-enhancing administrative and structural reforms by mobilising EU funds and technical expertise. Romania has requested support from the European Commission under Regulation (EU) 2017/825 on the establishment of the Structural Reform Support Programme ("SRSP Regulation"). The request has been analysed by the Commission in accordance with the criteria and principles referred to in Article 7(2) of the SRSP Regulation, following which the European Commission has agreed to provide technical support to Romania in the area of education, with the purpose of supporting the objectives of the Educated Romania project. The SRSS has awarded a grant agreement to the OECD in order to assist the Presidential Administration and the President of Romania with preparing a set of policy briefs in four thematic areas of the Educated Romania project. This policy brief focuses on educational equity, which touches on many dimensions of education policy. To focus the discussion, this brief will analyse three policy priorities that have been effective in closing achievement gaps in other countries (OECD, 2016 $\left.6_{[3]}\right)$. They are:

1. improving levels of functional literacy

2. reducing early school leaving

3. developing support measures to help early school leavers return to school. 


\section{Improving Educational Equity in Romania}

Ensuring that all students receive good quality education can promote inclusive growth and foster social cohesion. While the Romanian education system enables some students to excel, many still leave school early or without basic skills. In support of the Educated Romania - project of the President of
Romania, Klaus lohannis, a policy brief on this topic was funded by the European Union and implemented by OECD in cooperation with the European Commission's Structural Reform Support Service.
By 2020, the EU aims

to have less than

$\mathbf{1 5 \%}$ of 15 -year-old students perform below Level 2 in PISA.*
$<15 \%$

40\%

In PISA 2015, 40\% of students did not achieve Level 2 proficiency in at least one PISA subject.*

\section{International Advice}
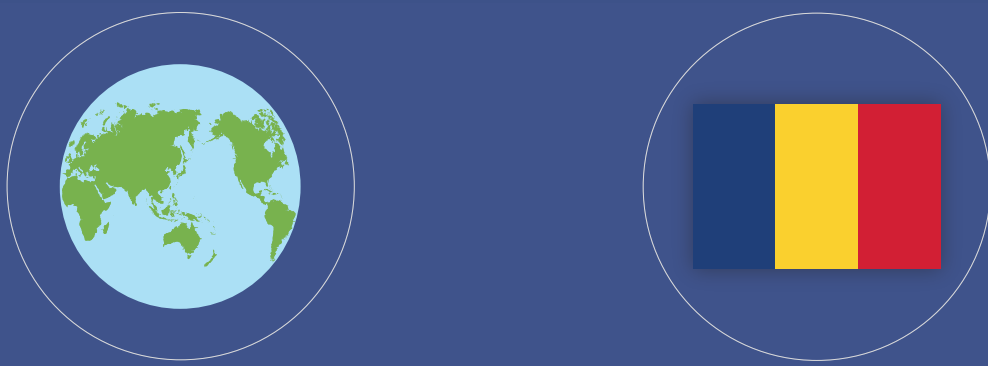

\section{Advice for Romania}

\section{IMPROVE FUNCTIONAL LITERACY}

Support students and schools.

Use reliable tools to diagnose learning needs.

Strengthen formative assessment.

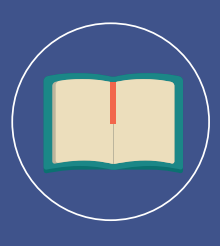

Focus on supporting students from disadvantaged backgrounds and the schools they attend. Identify students at risk of falling behind; national assessments and diagnostic tests can help.

Build teacher assessment capacity.

Support the success of all students, not just high performers.

\section{REDUCE EARLY SCHOOL LEAVING}

Engage parents and communities.

Motivate students to learn.

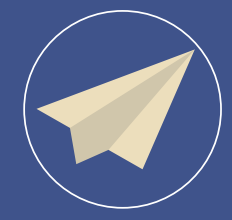

Reduce school segregation. Support teachers and schools in disadvantaged areas.
Continue parent education programmes, target most vulnerable communities.

Offer engaging curricula and mitigate negative impacts of selective exams.

Review student allocation model.

Provide additional resources and support teachers in rural schools.

\section{$\triangle$ HELP EARLY SCHOOL LEAVERS RETURN TO SCHOOL}

Develop flexible alternatives to mainstream education.

Collaborate and promote positive attitudes

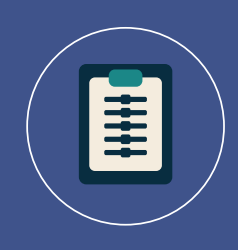

Offer second chance programmes to help individuals overcome existing learning barriers.

Offer clear and flexible education pathways and consider accrediting second chance programmes. 


\section{Policy priority 1. Improving levels of functional literacy}

Functional literacy means that individuals are able to locate and interpret information, then use it to solve problems routinely faced by adults in today's world. The OECD Programme for International Student Assessment (PISA) establishes baseline functional literacy as achieving a Level 2 or above in the core domains of reading, mathematics and science. Without this level of proficiency, students may struggle to participate fully in modern society. The European Union (EU) uses this measure as a benchmark to reduce underachievement in basic skills. Specifically, the EU has set a target that the share of low-achieving 15 -year-olds across the core domains of PISA should be less than $15 \%$ across all member countries by 2020 (European Union, 2018[4]).

Despite improvements, functional literacy in Romania remains among the lowest in the European Union, with around $40 \%$ of students not achieving baseline proficiency in at least one subject in PISA 2015. While Romania had the second largest drop in the share of low performers in mathematics among all PISA participating countries between 2006 and 2012 (see Figure 1), the proportion of students not reaching Level 2 in science and reading increased slightly between 2012 and 2015 (OECD, 2016[5]). Data from PISA 2015 also reveals that around $24.3 \%$ of students in Romania scored below Level 2 in all three subjects, putting them at a particularly high risk of failing in education and limiting their future careers. This was slightly lower than Bulgaria (29.6\%) but higher than other neighbouring EU countries, including Slovakia $(20 \%)$, Hungary (18.5\%) and Poland (8.3\%). It was also significantly higher than the OECD average (13\%). Romania's overall performance would likely be even lower if the nearly $20 \%$ of 15 -year-olds not enrolled in formal education were included in the PISA assessment (Eurostat, 2016 $6_{[6]}$ ).

Figure 1. Romania has reduced its share of low performers in maths across PISA cycles

Low performers in maths (percentage of students scoring below Level 2)

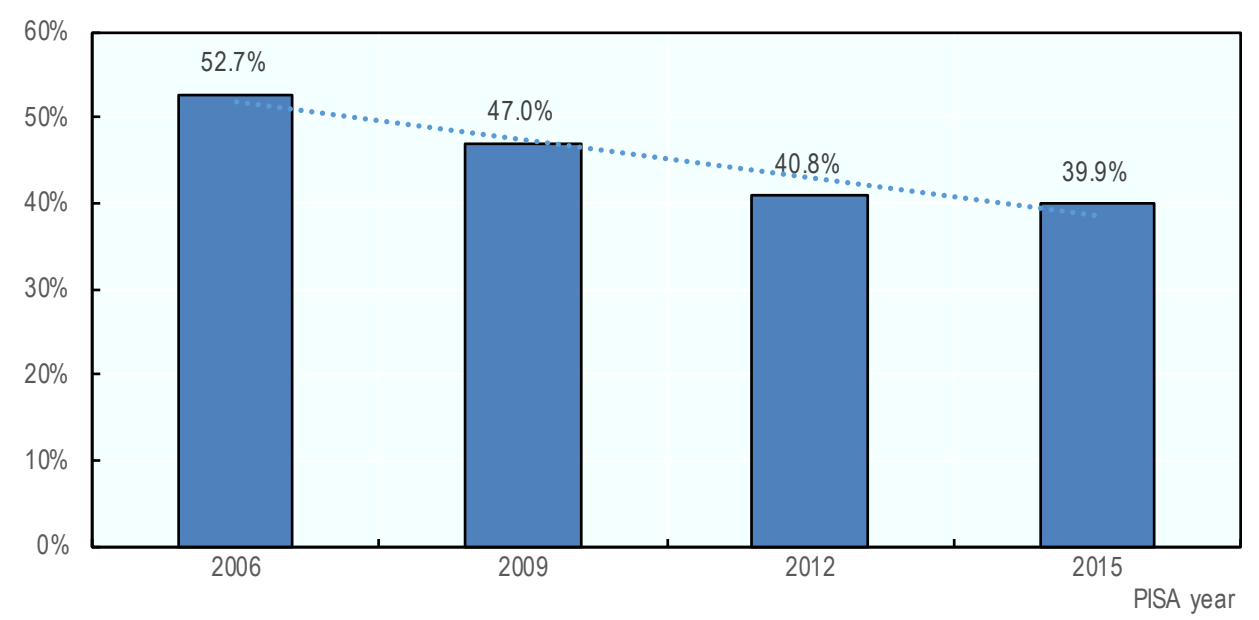

Source: (OECD, 2007[7]), PISA 2006: Science Competencies for Tomorrow's World: Volume 1: Analysis, https://doi.org/10.1787/9789264040014-en;

(OECD, 2016[8]), PISA 2015 Results (Volume I): Excellence and Equity in Education, https://doi.org/10.1787/9789264266490-en;

(OECD, 2010[9]), PISA 2009 Results: What Students Know and Can Do: Student Performance in Reading, Mathematics and Science (Volume I), https://doi.org/10.1787/9789264091450-en . 


\section{Factors associated with low-functional literacy}

Across all countries, socio-economic background is among the strongest predictors of student achievement: advantaged students performed better than their disadvantaged peers in all countries that participated in PISA 2015 in the three core domains that were tested (OECD, 2016[5]). Other important background factors include location of the school (in a rural area), gender (in many countries, girls tend to underachieve in mathematics; boys in reading and science), or immigration or linguistic background (ibid). Family composition (students from a single parent home are more likely to be low performers) and access to early childhood education (the longer students attend pre-primary education as a child, the higher they tend to score at 15 ) are other student level factors that are associated with low performance (OECD, $2016[5]$.

Policy factors can also contribute to low-functional literacy among students. For example, grade repetition and early tracking into vocational tracks are both associated with lower levels of student achievement. Additional factors relate to school resources, such as over-crowded classrooms, underqualified teachers or lack of learning materials, which in most countries affect schools in disadvantaged communities disproportionately, compounding socio-economic inequities. A negative school climate (including incidences of bullying) and unsupportive teacher-student relationships may also affect learning, in particular for disadvantaged students (Agasisti et al., 2018[10]). Finally, social and emotional well-being factors, such as life satisfaction, anxiety and achievement motivation can influence functional literacy, since students who report feeling engaged and accepted in their school communities perform better and are more motivated to do well in school (Cohen et al., 2009 [11]; Goodenow, 1993 ${ }_{[12]}$ ).

These factors are multiple and cumulative; however, they do not automatically mean that a student will have low-functional literacy. In fact, many countries have successfully reduced their share of lowperforming students (OECD, 2016[3]). While these countries have diverse starting points, different systems and unique contexts, several policy interventions have shown to be consistently effective, such as:

- addressing structural issues around low performance (e.g. allocating resources to support equity goals and early education, see policy brief on early childhood education and care)

- introducing targeted interventions to identify and support low-achieving students and schools.

These approaches can help guide Romania's efforts to reduce the high share of students with lowfunctional literacy and raise overall equity in education.

In Romania, low-functional literacy is associated primarily with socio-economic background, living in a rural area and student ethnicity (e.g. Roma students have particularly poor outcomes). The difference in reading performance on PISA 2015 between Romanian students from the highest socio-economic quartile and the lowest was 93 points (OECD, 2016 $\left.{ }_{[5]}\right)$. While this gap is smaller than in some European countries, including Bulgaria (124 points), it remains larger than Moldova (89 points) and the OECD average (86 points). Moreover, only $11.3 \%$ of all Romanian students were shown to be "resilient" in PISA 2015, meaning that they overcame their low socio-economic background to perform in the top quarter of students. In contrast, neighbouring countries such as Slovenia and Croatia are more effective at helping students to realise their potential, with shares of "resilient" students closer to the OECD average of 29.2\% (OECD, 2016a).

Disadvantaged students with low-functional literacy are more likely to leave school early, especially boys living in rural areas and Roma students. These students are particularly vulnerable to drop out during the transition from lower to upper secondary education, a main weak point in Romania's education system since enrolment rates decrease by 5 percentage points between ages 14 and 15 (Kitchen et al., 2017[1]). Aware of these challenges, Educated Romania has requested guidance on:

- How to improve the level of functional literacy to improve equity? 


\section{Potential impact}

Improving functional literacy to meet EU and OECD benchmarks would not only have a positive impact on the opportunities and outcomes of individuals in Romania, but also contribute positively to social cohesion and national development. In line with the Europe 2020 strategy for smart, sustainable and inclusive growth, Romania is working towards a set of education targets established by the EU. Specifically, these include reducing the share of early school leavers to less than $10 \%$ and increasing tertiary attainment among 30-34 year-olds to $40 \%$ by 2020 (European Commission, $2018_{[13]}$ ). As of 2017, the rate of early leaving from education and training in Romania was $18.1 \%$ and the tertiary attainment rate among $30-34$ year-olds was $26.3 \%$ (ibid.). Achieving EU targets would mean that a larger share of young Romanians would benefit from more learning time, which if well used could help improve overall levels of functional literacy.

Higher levels of literacy could also facilitate the transition of students from education to work, improve labour market outcomes and support future economic growth. In 2017, 15.2\% of young adults (15-24 year-olds) in Romania were not in education, employment or training (NEET), one of the highest rates among EU countries (European Commission, 2019[14]). More students achieving higher levels of functional literacy will help to increase the number of students who progress to and complete a tertiary level of education. Youth who achieve this level are less likely to be unemployed than those who only attain an upper secondary education level or less (Eurostat, 2016 $\left.6_{[6]}\right)$. Since educational attainment and earnings are highly correlated, improving the functional literacy of Romania's lowest achievers and expanding their opportunities to continue to higher education could help reduce income inequality, which in Romania is the highest in Europe (Eurostat, 2016[6]).

\section{International evidence and experience}

Several countries have introduced initiatives to support all students in achieving a baseline level of functional literacy. The following approaches have been successful elsewhere and may help to address this challenge in Romania:

\section{Early diagnosis of learning needs}

Diagnostic assessments help identify a student's knowledge and understanding at the beginning of the year or unit of learning (OECD, 2013[15]). Importantly, these assessments are formative, meaning they carry no stakes for students but rather are designed to support teachers in meeting the individual learning needs of students. Since children start school with heterogeneous levels of learning - especially in Romania where attendance in early childhood education and care is highly variable - using age appropriate diagnostic assessments early on can help detect students at risk of falling behind. This allows teachers to intervene to appropriately scaffold learning or provide additional supports while the child is still young. Such measures are more effective the earlier they begin and can ensure that students do not move thorough grades accumulating major gaps in their learning, which is currently a concern in Romania (Kitchen et al., $\left.2017_{[1]}\right)$.

\section{National assessments}

While standardised national assessments are often used to monitor learning at the system level, many OECD countries also conduct them on a census basis in order to provide teachers, schools and parents with information about individual student performance compared to national learning standards (OECD, 2013[15]). National assessments offer objective, valid and reliable measures of what students know and can do, which can complement teacher-led classroom assessments. Information from national assessments can help teachers identify students at risk and adapt their instruction to meet learning needs. Romania has full cohort national assessments in Grades 2, 4 and 6; however, these are not fully standardised and the purposes of the assessments are not clear, in particular for teachers. As a result, existing national assessments do not provide reliable information for system monitoring nor is the data 
being used formatively in most schools. In 2017, the OECD recommended that Romania standardise the grade 4 assessment and consider introducing a sample-based national assessment for system monitoring in lower secondary education in the medium term (Kitchen et al., 2017 $\left.{ }_{[1]}\right)$. This would provide information on student learning outcomes at multiple stages in the education system and allow for the comparison of student progress across grades. The OECD recommended that the assessments in Grade 2 and 6 continue to be administered by teachers to the full cohort of students, but with much more support on how to grade student work in relation to national standards. Over time, as the reliability of teachers' professional judgement improves, these assessments might be replaced by teacher designed diagnostic tests.

\section{Diagnostic assessments}

The Education Endowment Foundation (EEF) in the UK recommends that teachers administer diagnostic assessments at the start of each new topic. This can be especially beneficial for low-performing students because unidentified learning gaps often prevent them from receiving the support they need to avoid falling behind or result in their disengagement with school. These assessments can be developed centrally and resemble "tests" (see Box 1) or may consist of informal and fun exercises that provide accurate information. The latter may be especially relevant for diagnostic assessments in the early years of schooling. Information from diagnostic assessment allows teachers to uncover possible reasons why students may be struggling (i.e. whether the activity is too hard or too easy, if a student is disengaged with the material, if the student has gaps in prior learning or has misunderstood an important point).

\section{Box 1. Diagnostic assessments in French primary schools}

In France, students who enter elementary school (cours préparatoire) are evaluated as part of a national diagnostic evaluation in French language and mathematics. The French language assessment focuses on basic literacy skills and knowledge and evaluates a student's ability to communicate orally, their phonological awareness and their knowledge of the alphabet. In mathematics, the assessment focuses on counting and reading numbers up to ten. The evaluation is a written assessment, with each student receiving a booklet where they respond to the questions. Teachers also receive a booklet that provides detailed guidance on how to administer the assessment to the whole class. Student booklets are collected in the end and evaluated by a student's classroom teacher.

The diagnostic assessment provides the teacher with information so that they can adapt their teaching practices to students' needs. It also provides school inspectors with information to understand the needs of the schools within their district, enabling them to provide relevant support to the teaching staff. The results are also shared with parents, and together parents and the student's classroom teacher discuss how to best support the student's learning and development needs. Results are also anonymised at the school-level and shared with the relevant district to provide direction for future professional development training for teachers.

Source: (Ministère de l'Éducation Nationale, 2018[16]]), Évaluations Diagnostiques en CP [Diagnostic Evaluation in CP], http://eduscol.education.fr/cid119562/evaluation-diagnostique-en-cp.html.

\section{Additional support for learning}

Personalised learning support and student-centred pedagogies can be particularly beneficial for students with low-functional literacy who are at risk of disengagement (Black, 2007 $[17])$. Among the different types of additional support, research suggests that targeted small group and one-to-one interventions have the largest potential for immediate impact on student attainment (EEF, 2018 $\left.{ }_{[18]}\right)$. Some whole-class and whole-school interventions have also shown promise but may take longer to show results (ibid). 
Other options to extend remedial learning support might include making school staff available to help students with their homework and designating spaces for this activity to happen after school hours. Additional learning support is particularly important during transition years as students often face challenges during their first months in a new learning environment. Finally, multi-tier intervention models that allow educators and other professionals to address a range of individual learning needs can help ensure that students who risk falling behind get the support they need. Romania could consider some of these arrangements to help improve levels of functional literacy.

\section{One-to-one tuition}

One-to-one tuition involves a teacher, teaching assistant or other adult working to give a student intensive individualised support $\left(E E F, 2^{2018_{[18]}}\right.$ ). It can take place in addition to normal lessons (i.e. by extending school time) or as a replacement for other lessons. Evidence from the United Kingdom suggests that short, regular sessions that link with normal lessons and are held over a set period of time seem to produce the best results (ibid). Sessions can be one-to-one or organised in small groups of two or three students. This intervention can be costly. Therefore, in order to ensure the investment is effective, it is important to train the teaching assistants and volunteers who lead the tuition.

\section{Multi-tier intervention models}

Supporting students with low-functional literacy is a team effort that sometimes requires commitment and expertise from a range of professionals. Members of support teams may include school principals, psychologists, social workers, school nurses, special educators and occasionally speech therapists or medical doctors. The composition of support teams and the intensity of their work can vary by school size, type and location. Together, they can offer calibrated interventions to students at risk of falling behind. For example, Finland has a three-tier intervention system that progressively intensifies the type of support offered (see Box 2). 


\section{Box 2. Multi-tier intervention in Finland}

In 2007, Finland introduced a new Special Education Strategy in response to concerns expressed by several municipalities about the increasing number of students referred to Special Education Needs (SEN) support. Such multi-tier intervention models can also support the early identification of students who are at risk of dropout or grade repetition. The new strategy introduced a three-tier level of support to students at risk of falling behind:

- Tier 1: General support is accessible to all students and includes further in-class differentiation of learning; remedial teaching; co-teaching with specialised education needs teacher and part-time special education support. Organisation of this support is left at the discretion of the classroom or subject teacher.

- Tier 2: A learning plan for intensified support is prepared for students who need additional support. Teachers identify the students at risk through a pedagogical assessment and develop an action plan. The plan is often the same as the Tier 1 support but implemented more intensively. It is left to the school to decide on whether to offer other evidence-based targeted interventions.

- Tier 3: Special support is available when Tier 2 has proven ineffective to meet a student's needs. A pedagogical evaluation is conducted by multi-professional team in the school. Access to Tier 3 support requires confirmation by the Municipality. The planned actions are specified in an official document the "Individual Education Plan" which has to be monitored and adjusted regularly.

- Almost every school in Finland has multi-professional support teams that help teachers implement the multi-tier approach. In bigger cities and towns, the core team is present at school every week, which makes it easy to have regular meeting times. In remote areas, some professionals may be present only once or twice a month.

In the majority of the Finnish schools, the teams meet weekly or bi-weekly to design and co-ordinate school- and class-level preventative work and general interventions. The team also monitors the situation of each class in the school to identify students at risk of falling behind in their learning. In practice, every class teacher or class supervisor attends the team meeting at least once a year to go through the situation of their class and the individual students in it in detail.

Source: (Thuneberg et al., 2014[19] $)$, Conceptual change in adopting the nationwide special education strategy in Finland, http://dx.doi.org/10.1007/s10833-013-9213-x;

(Ahtiainen et al., 2012[20]) Tehostettua ja erityistä tukea tarvitsevien oppilaiden opetuksen kehittäminen 2007-2011,

http://julkaisut.valtioneuvosto.fi/bitstream/handle/10024/79219/okm05.pdf?sequence=3\&isAllowed=y.

\section{Strengthen formative assessment in classroom teaching}

Formative assessments support learning. They take place frequently during the learning process to identify a student's strengths and weaknesses in a particular area and are used to help shape future instruction and improve subsequent learning (OECD, 2013 $\left.{ }_{[15]}\right)$. Formative assessment tends to favour qualitative judgements over numerical marking (like grades), especially in the early years. Studies have found that quality formative assessment practices can have a significant positive impact on student achievement and can help accelerate learning - enabling students to learn in eight months what would normally take them a year (Wiliam, 2010[21]; Black and Wiliam, 1998[22]). As such, formative assessment can be a particularly powerful tool for low-achieving students who may feel discouraged by low grades and need extra time to meet national learning standards.

Importantly, formative assessment relies on the capacity of teachers to use effective questioning techniques and interactive dialogues to explore student understanding (as well as the source of 
misconceptions). Then adjust their teaching strategies to meet student needs. Currently, Romanian teachers receive limited practical education on how to use formative assessment in their classroom practice. As a result, summative assessment (which takes place at the end of learning) continues to dominate assessment culture (Kitchen et al., 2017[1] $)$. To encourage greater use of formative assessment among teachers, Romania could:

- Develop a national policy statement on the value of formative assessment for education;

- Review initial teacher education and professional development programmes to ensure that they equip teachers with strong assessment literacy;

- Develop a range of resources and tools (including national assessments) to enhance the assessment practices of teachers, in particular with respect to identifying individual learning levels and needs and monitoring student progress in relation to curriculum goals (OECD, 2005[23]; OECD, 2013[15]).

- Promote formative assessment by increasing its value in teacher appraisal and school evaluation and reducing the weight given to high-stakes examinations;

- Encourage teachers to involve students in the assessment process by discussing learning goals and sharing examples of success;

- Establish peer learning networks focused on formative assessment so that teachers can share effective techniques and approaches (e.g. how to make feedback more descriptive, constructive, timely and specific);

\section{Setting high expectations for all students}

Part of improving functional literacy is setting high expectations for all students, not just the top performers. School leaders and teachers sometimes respond to low-performing students by lowering their expectations for these students and even reducing the scope of the curriculum they are exposed to (OECD, 2016 $\left.6_{[3]}\right)$. In turn, this can lower the expectations students have for themselves and contribute to disengagement and poor performance at school (Eder, 1981 [24]; Rist, 2015[25]). There are systemic issues in Romania that encourage teachers and school leaders to have low expectations for certain groups of students (or focus narrowly on high performers). These include:

- High-stakes exams and early tracking. The results of Romania's grade 8 examination are used to track students into different high schools - theoretical, vocational and technological high schools. Students who score highly in the examination are more likely to gain a place in the more prestigious theoretical schools. This system encourages teachers to focus on the top-performing students, and measure student success in terms of high marks and entry to an elite high school. Students who do less well in academic tests tend to receive less support and are directed towards vocational programmes independent of whether this meets their learning interests and goals (Kitchen et al., 2017 ${ }_{[1]}$ ).

- Olympiads and academic competitions. Romania's salary bonus scheme rewards teachers, among other things, for preparing students for, and winning academic Olympiads (MNESR, 2016[26]). This has ingrained a culture of academic competition that encourages teachers and schools to narrowly focus on the top-performing students. As a result, there is a risk that students who might be struggling to develop their functional literacy skills will receive less attention (Kitchen et al., 2017[1]).

- Teacher appraisal and school evaluation. Student results in Romania's national exams and academic competitions are part of the criteria used to appraise teachers and evaluate schools. While data on student learning outcomes plays an accountability role in monitoring system performance, using raw student results in this way can create the perception that teachers and schools should focus on high marks rather than helping all students to reach national learning expectations. 
The OECD Review on Evaluation and Assessment in Education: Romania recommended a series of measures to address these concerns, including:

- Review pathways and certification in secondary education to ensure that all students benefit from equal educational opportunities and receive recognition for their achievements.

- Reward and incentivise teachers' development of higher competency levels by developing a new teacher career path that recognises and rewards teachers as they develop professionally and take on new roles and responsibilities (see policy brief on the teaching profession), rather than rewarding teachers for having high-achieving students. This may involve instituting a general increase to teacher salaries to attract top candidates and provide sufficient remuneration.

- End the unfair practice of using Grade 8 examination results to rank and sanction schools. Instead, the OECD recommended providing the public with more descriptive information about the school, like the socio-economic status of the school community and other factors that affect student learning to contextualise examination results.

\section{Effective implementation and capacity development}

According to the 2011 Education Law, Romania's education system is governed by a set of principles that include fairness, quality, relevance, efficiency and public responsibility. While these principles provide a basis to establish a more equitable education system, implementation of the Education Law has been mixed, partly because of changes in policy direction and political leadership (Kitchen et al., 2017 ${ }_{[1]}$ ). Improving functional literacy for all Romanian students not only requires a strong commitment to support struggling and disadvantaged students. It also requires sustained policy implementation and capacity within the system to deliver reforms. As well as the individual measures highlighted above, Romania could consider some of the following arrangements to provide a concerted and coordinated approach across the education sector:

\section{National target setting}

The current discussion around the Educated Romania initiative has helped launch a national debate on education and created an opportunity to forge a longer-term vision for education. Setting a limited number of goals over the medium term could support monitoring and accountability, and provide evidence on key priorities to inform policymaking. Setting clear goals and defining plans of action according to these goals is important on both the national and school level as it helps ensure that all actors in the system are working towards a common purpose. Creating prominent national goals to improve functional literacy will also help to galvanise change by focusing education actors and society on the competencies that children and young adults are expected to develop at school. This might include:

- Using data from the country's national (and international) assessments and national examinations to set goals and monitor progress. Goals might focus on increasing the share of students who meet basic national standards in the short to medium term. This would support Romania's efforts to achieve long-term goals, such as those set out by the European Union: that less than $15 \%$ of 15 -year-olds in Europe have low basic skills by 2020 .

\section{Capacity building}

Much of the responsibility for improving functional literacy in Romania depends on teachers. Their capacity to identify and use appropriate diagnostic assessments, as well as to integrate formative assessment into regular classroom practice are key to helping students reach their potential and stay in school. To build the assessment capacity of teachers, Romania could develop competency profiles and standards for both teachers and school leaders (see policy briefs on the teaching profession and professional education management and leadership). These standards will need to recognise the competencies, such as how to address and support disadvantaged learners and their families. Romania could also build teachers' 
repertoire of teaching approaches to meet diverse learner needs by providing school-level support for teaching and learning (see section on school experts mentioned in the teacher policy brief). Teachers might also benefit from support in how to use evidence of student learning to design future learning and appropriate interventions. Box 3 provides an example of how trainee teachers in Scotland (United Kingdom) are being supported to address the literacy needs of struggling learners.

\section{Box 3. Support for struggling students in Glasgow, Scotland (United Kingdom)}

The Strathclyde Literacy Clinic in Glasgow, Scotland provides opportunities for trainee teachers to work with struggling learners. The trainee teachers learn to consider a range of evidence to inform their intervention decisions, and to make evidence-based decisions about how to improve a child's literacy. The teachers work in teams of four to discuss their diagnosis, as well as participate in tutorials in their academic programmes. Interventions last from one to ten weeks. They usually work in a group of four trainee teachers and give pupils lessons once a week for ten weeks. University teacher educators lead tutorials in which the case studies are shared and discussed. Each year, approximately 120 trainee teachers work with 30 children.

The project is based in a high-poverty area of Glasgow. Evidence shows it changes student teachers' understanding of how poverty affects literacy and educational attainment. As a collaborative learning experience for the student teachers, it has a strong emotional and social dimension and, importantly, builds a strong sense of professional agency. The students (primary age) generally increase make gains in reading attainment, advancing up to 12 months during a 10 week period.

Source: (Elinet, n.d. [2]]), Strathclyde Literacy Clinic, website, www.eli-net.eu/good-practice/examples-of-good-practice/detail/project/strathclyde-literacy-clinic;

(Thomson, n.d. [28]), "The Strathclyde Literacy Clinic" University of Strathclyde Glasgow website, https://pureportal.strath.ac.uk/en/projects/the-strathclyde-literacy-clinic.

\section{Co-ordination}

Ensuring that policies targeting students with low-functional literacy are coherent with other policy areas is an important part of the implementation process. For example, since support in the early years is crucial to the development of a child's functional literacy, school level policies should align with efforts to improve access to early childhood education and care (ECEC) for disadvantaged families (see policy brief on early childhood education and care). Wider structural reforms - which are beyond the scope of this policy brief will also need to be addressed. These include institutional commitment to long- term policy reforms, as well as sufficient funding. Attention to the distribution of funds to disadvantaged areas need also to prioritised, along with rural development. 


\section{Policy priority 2. Reducing early school leaving}

The European Union (EU) defines early leavers from education and training as people aged 18-24 who have attained at most lower secondary education and are not involved in further education or training (European Education Council, 2003[29] $)$. The costs associated with early school leaving are similar to those associated with low-functional literacy discussed in policy issue 1. Meeting the EU target of reducing the average early school leaving rate across member countries to less than $10 \%$ by 2020 can help achieve other European targets, such as raising the employment rate and reducing poverty (European Commission, 2011 $[30]$ ).

Romania's national European target for 2020 is to reduce the early school leaving rate to $11.3 \%$ (European Union, 2018[4]). However, as of 2017, Romania's early school leaving rate $(18.1 \%)$ was much higher than both the national Europe target and the EU average (10.6\%). Moreover, while most EU countries have made progress towards achieving the 2020 target since 2011, Romania remains the only country with a high share of early school leavers that saw no significant change between 2011 and 2017 (see Figure 2) (European Commission, 2018[13]). There are recent signs that the persistently high rate of early school leavers is finally starting to decrease: provisional data from 2018 reveal Romania's early school leaving rate is now $16.4 \%$ (Eurostat, $2019_{[2]}$ ). However, this is still higher than the national and European targets.

Figure 2. Early leavers from education and training, 2011-2017

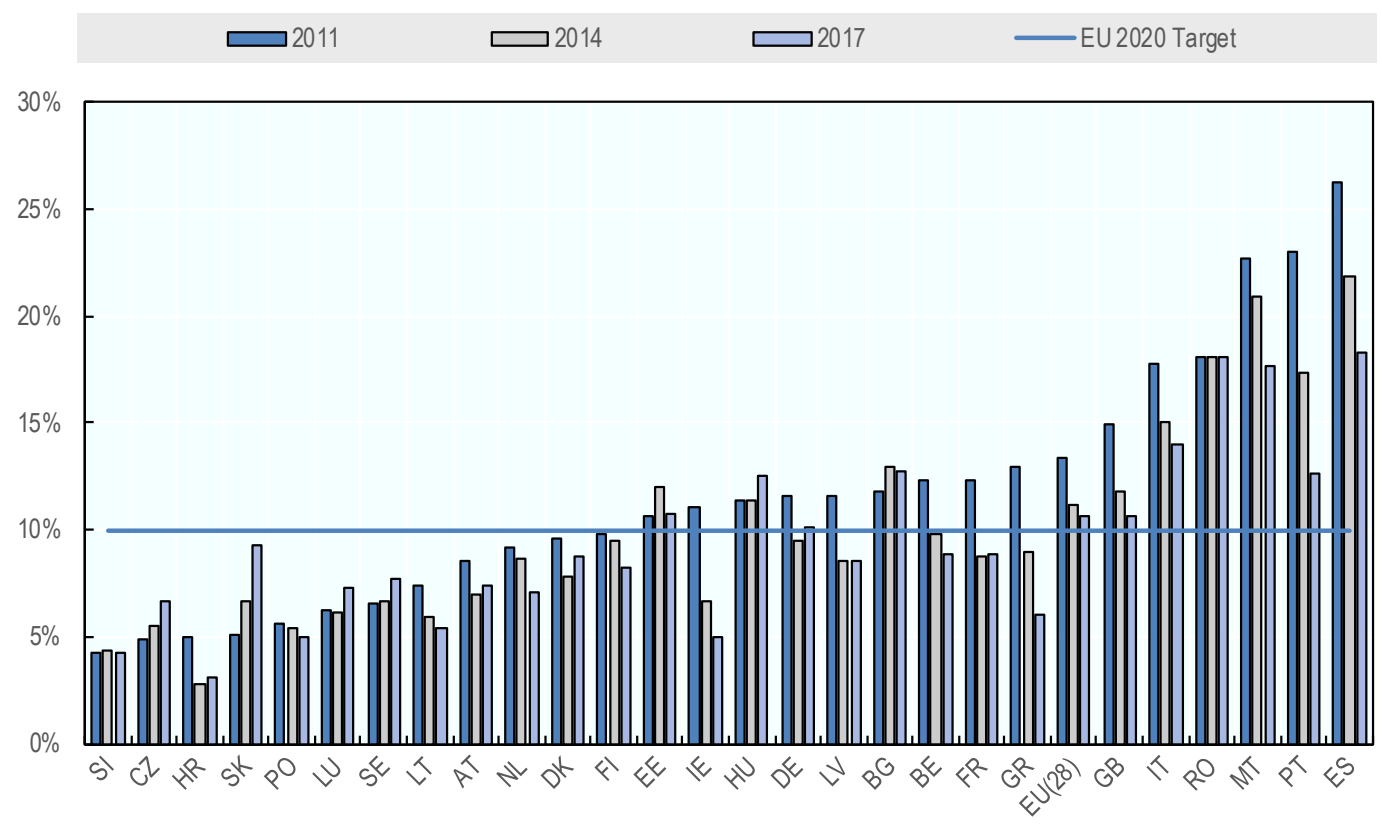

Source: (Eurostat, 2016[6]), Education and Training (database), https://ec.europa.eu/eurostat/data/database (accessed 05 March 2019). 


\section{Factors associated with early school leaving}

Several factors can contribute to early school leaving. These might relate to household issues, such as a family's low income level, negative or low perceptions of the benefits and prospects associated with education, or individual factors, such as the child being involved in seasonal work, having to care for younger siblings or having health related issues (MNESR, 2015 $5_{[31]}$ ). The school learning environment and a student's progress in school also affect retention, meaning that early school leaving and educational concerns, such as low-functional literacy (policy issue 1), are often closely related. At the same time, early school leaving can be influenced by supply-driven factors, such as the limited availability of second chance and initial vocational education and training (VET) programmes, especially in rural areas, lack of communication with different actors in the school community (including parents and families) and weak links between education offers and labour market demand (ibid). Despite these multiple risks, many European countries have successfully lowered their shares of early school leavers, demonstrating that it is possible to reverse negative trends. In particular, these countries:

- Use a whole school approach to identify students at risk and monitor their progress;

- Provide targeted academic, social and emotional support for children to enhance their sense of belonging in the school community;

- Prioritise linking schools with parents and communities;

- Offer engaging curricula that motivates students to learn (OECD, 2012[32]; School Education Gateway, 2016[33]).

Taken together, these approaches can help guide Romania's efforts to reduce the high share of early school leavers and raise overall equity in education.

In Romania, there are noticeable disparities in regards to the groups of students who are most vulnerable to early school leaving. The rate is particularly high among students from Roma communities $(77 \%)$ (European Commission, 2018[13]) and those living in rural areas (25.4\%) (Eurostat, 2018[34]). There are also points within a student's school trajectory when they are especially at risk. As seen in Figure 3 , the enrolment rate drops by 5 percentage at the beginning of the upper secondary level (after the eighth grade). The rate also drops significantly after the completion of compulsory education (tenth grade). This marks the transition from lower to upper secondary education as a particularly vulnerable point in the education system. Since most general and professional upper secondary schools are located in urban areas, students in rural areas from socio-economically disadvantaged families often struggle to afford the transport and accommodation costs of sending their children to urban upper secondary schools (European Commission, 2019 $\left.{ }_{[14]}\right)$. Selection based on examinations at the end of lower secondary and the perceived poor quality and relevance of upper secondary VET education, together with limited access to tertiary education, are other factors behind the sudden fall in Romania's student population at the age of 15 (Fartuşnic et al., 2014[35]). 
Figure 3. Weak points for school leaving in the Romanian education system

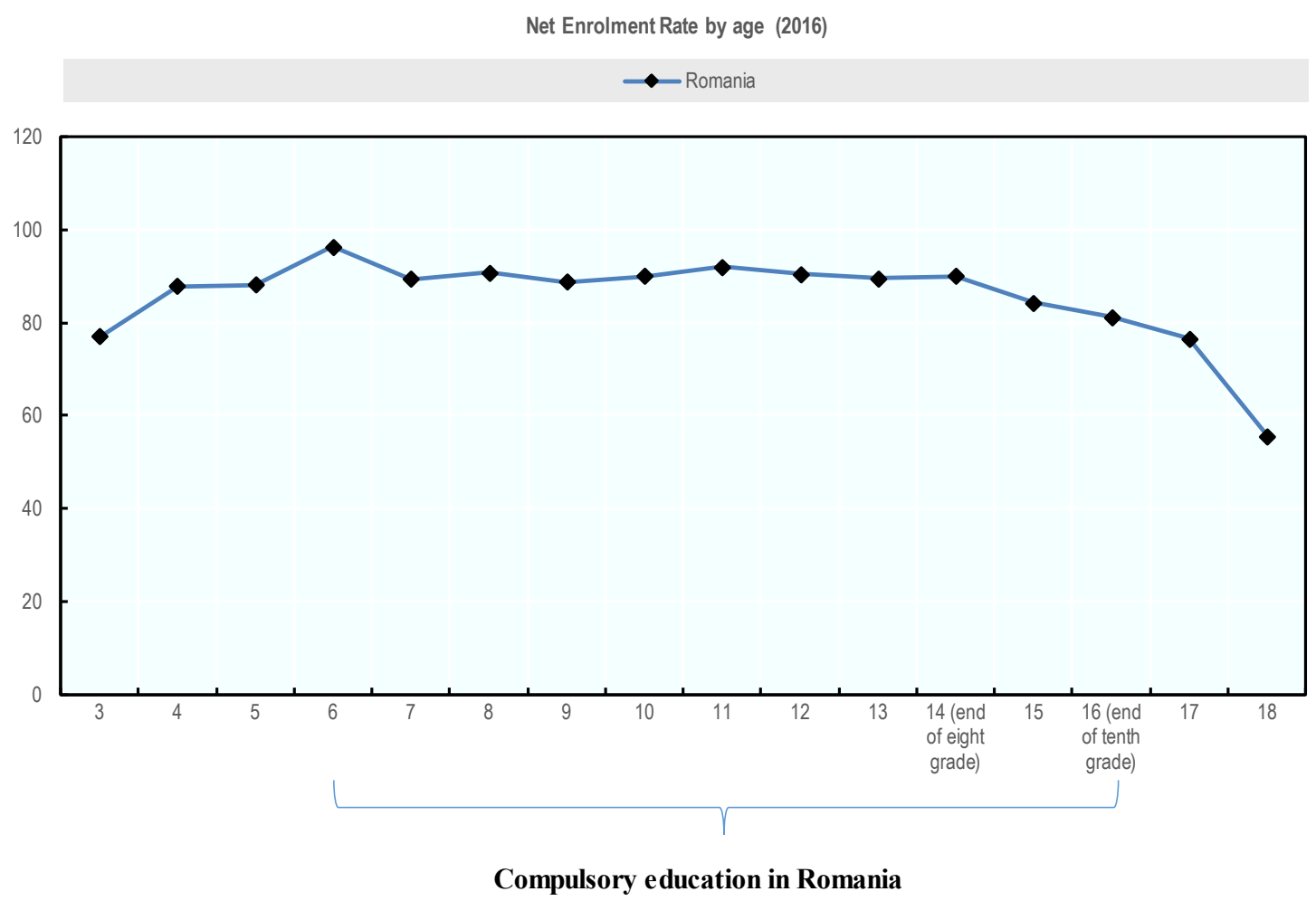

Source: Authors' calculations based on (Eurostat, 2016[6] $)$ Education and Training (database), https://ec.europa.eu/eurostat/data/database (accessed 23 April 2019).

To address this challenge, Romania has adopted a National Strategy to Reduce Early School Leaving and is developing an early warning system to identify at-risk students. These efforts are helping improve the Romanian government's institutional capacity to plan, implement and monitor school leaving programmes. For example, Romania has introduced after-school remediation programmes, integrated services in schools and second chance education programmes; however, the reach of these initiatives is limited and some are yet to be fully implemented (Kitchen et al., 2017 ${ }_{[1]}$ ).

While addressing social barriers to school participation are important, Romania has been less successful in matching these efforts with increases in the quality and relevance of teaching and learning in schools (Horga, Irina; Jigău, Mihaela; Apostu, Otilia, 2017[36]). Romania's new competency-based curriculum has the potential to introduce a student-centred approach to education but implementation has not been consistent across the country (European Commission, 2019[14]). Moreover, Romania's school funding model, the relatively lower qualifications of teachers in rural areas and current merit allowances do not focus enough on improving the outcomes of disadvantaged schools and students (see policy briefs on teaching profession and professional management in education). Aware of these challenges, Educated Romania asked for support on:

- How to improve access to quality education, improving student retention and reducing early school leaving, especially in rural and poor areas.

\section{Potential impact}

Reducing early school leaving is essential for achieving a number of key national objectives. For example, it can help reduce Romania's share of NEET, and rates of poverty and unemployment. It can also help achieve the aims identified in the Europe 2020 strategy for smart and inclusive growth by improving education and training levels for all young people (MNESR, 2015 [31]). Reducing the average European 
early school leaving rate by just one percentage point could provide the European economy each year with nearly half a million additional qualified potential young employees (European Commission, 2011 [30]). Finally, reducing the number of early school leavers can improve the life chances of individuals who will be more likely to support their children's learning in the future, thus breaking the cycle of low achievement (Schuller, 2017[37]).

\section{International evidence and experiences}

Romania's national strategy on reducing early school leaving includes professional development for teachers who work with vulnerable student groups. It also aims to strengthen the government's capacity to address early school leaving, namely by developing an early warning system to detect at-risk children. These promising initiatives resemble some of the approaches used by other countries to lower early school leaving rates. The measures highlighted below have been successful elsewhere and are intended to help Romania reinforce its strategy on reducing early school leaving by improving the mix of support measures that can help keep students in education for longer. It is important to note that low performance in school can be one of the leading factors that encourages students to abandon their education; therefore, many of the measures discussed in the first policy priority of this brief are also relevant here.

\section{Engage parents and local communities}

Parental engagement in education might involve supporting learning at home, such as helping with homework, or taking part in school-based activities, like participating in parent-school meetings (Dumont, Istance and Benavides, 2010 ${ }_{[38]}$; Nusche, 2009 ${ }_{[39]}$. In fact, the relationship between schools and communities has changed in recent decades as parents and community members increasingly engage in school life by taking responsibility for managing schools and helping teachers bring the outside world into their classrooms (OECD, 2013 $3_{[40]}$ ). When parents are involved in their child's education, it can encourage positive attitudes towards school, improve homework habits and achievement, and reduce absenteeism, disengagement and dropout (OECD, 2012[32]). Compared to more affluent parents, disadvantaged parents tend to be less involved in their children's schooling for multiple economic and social reasons (West, $2007_{[41]}$ ). For example, these parents may lack flexible work hours or have little formal education, which might make it difficult to participate in and monitor their child's schooling (OECD, 2012[32]). This is concerning since student socio-economic background correlates with early school leaving.

Policies that prioritise communication between schools, parents and communities can help align efforts to keep students in education. Engaging parents and communities allows education systems to address some of the non-school factors that may drive early school leaving, such as poverty or a challenging home environment. In Romania, the Ministry and the United Nations Children's Fund (UNICEF) have introduced parenting education programmes to increase awareness about the importance of education and regular attendance, provided training to equip schools with ideas and tools to enhance parental involvement and are currently developing a National Strategy for Parenting Education (UNICEF, 2017[42]). These are important steps towards reducing early school leaving in Romania, and may be extended and further developed if evaluation demonstrates their effectiveness.

Strategies that target parents who are disengaged and difficult to reach can be especially effective. For example, the Council of Europe developed a guide for Roma School Mediators that offers support for schools to effectively engage with Roma communities and the parents of Roma children (Rus and Zatreanu, 2009 $9_{[43]}$. Considering the high early school leaving rate for Roma students, Romania might consider using targeted approaches like this to reach some of the most vulnerable students and their families. Box 4 discusses how a school in Spain actively engaged Roma parents and families in an exercise to support school quality and reverse educational exclusion. 


\section{Box 4. Including Roma parents in school decision-making in Spain}

Spain has introduced several initiatives to reduce its early school leaving rate. The country's Programme to Reduce Early Dropout in Education and Training (2014-20) provides funding for preventive measures to detect early difficulties in learning and minimise the risk of dropout. Spain also conducts research on the causes of early school leaving and the profile of students who are at risk. Awareness campaigns that target students who are particularly vulnerable to early school leaving and their families also help to address this issue. La Paz Primary School in Albacete, Spain is one example of how a school has actively engaged parents to help strengthen overall performance and reduce early school leaving.

La Paz Primary School serves a community that is $90 \%$ Roma, struggles with very high dropout and absenteeism rates, and has low educational achievement. To help improve this situation, the school implemented a Dialogic Inclusion Contract based on a large-scale EU funded research project called INCLUDE-ED, Strategies for Inclusion and Social Cohesion in Europe from Education. The project involved all school stakeholders (parents, teachers, community members and students) in creating an egalitarian dialogue about the kind of school they would like, or their "dream" school. Teaching staff actively ensured spaces and opportunities for Roma families to participate, which brought their interests and concerns to the fore. For example, Roma parents expressed the desire for their children to finish compulsory education but explained that the location of secondary schools and stigmatisation towards Roma people outside of their own communities were major barriers.

Including Roma parents in the decision-making process of the school helped to reduce the Roma children's exclusion from the education system and helped transform pre-existing prejudices that Roma parents were not interested in education. The exercise has helped the school increase attendance, graduation, transition and achievement rates. Initiatives that actively engage hard to reach parents and families, like the Dialogic Inclusion Contract, have contributed to the gradual decline in Spain's national rate of early school leavers from $31.7 \%$ to $18.3 \%$ between 2008 and 2017.

Source: (Flecha and Soler, 2013[44]), Turning difficulties into possibilities: Engaging Roma families and students in school through dialogic learning, https://doi.org/10.1080/0305764X.2013.819068.

\section{Student drive and motivation}

Research shows that student drive and motivation, among other factors, are associated with student achievement (Dweck, 2006 $\left.{ }_{[45]}\right]$. Motivated students tend to have greater resiliency and are more tenacious in the face of academic challenges. However, there can also be downsides to achievement motivation, particularly when motivation is a response to external pressure. Results from PISA show that countries where students are highly motivated to achieve also tend to be the countries where many students feel anxious about a test, even if they are well prepared for it (OECD, 2017[46]).

In Romania, as students prepare for examinations they begin to resist classroom practice they see as irrelevant to test preparation (Kitchen et al., 2017[1]). The existence of a high-stakes examination at the end of Grade 8 means that this affect starts earlier in Romania than in many countries. Final Grade 8 results include marks from school assessments starting in Grade 5, which further exacerbates the focus on summative test results. While this may encourage student engagement with the wider school curriculum, it also means there are high stakes attached to student classroom work from the start of lower secondary education. As a result, students may be less likely to reveal gaps in their learning or feel it is unsafe to make mistakes because this will have important consequences on their future. It also risks undermining the motivation of students who tend to do less well in academic tests. These students risk 
falling behind and may disengage with school as a result. Those students who perceive that they will never perform well on the examination may drop out of school altogether.

As mentioned, data on drop out in Romania suggest that vulnerable points in the school trajectory occurs during the transition to upper secondary school (after grade 8) and after completing compulsory education (after grade 10). Romania's high-stakes examinations may be contributing to early school leaving since dropout rates in Grades 11 and 12 (prior to taking the baccalaureate exam) are higher among groups of students who tend to perform less well in the Grade 8 examination (Fartuşnic et al., 2014[35]). This is reflected in the fact that an increasing share of eligible students in technological high schools and those attending high school in rural areas (where schools are scarcer and the pass rate is significantly below the national average) are choosing not to the take the baccalaureate exam.

To keep students in school, some countries have deliberately raised the minimum school competition age. Prior to 1999, compulsory education in Romania was eight years and the current duration is 11 years, ending after Grade 10 when students are 16/17 years old. This is lower than Belgium, Germany, the Netherlands, Portugal and Macedonia but higher than other countries in the European Union (European Commission/EACEA/Eurydice, 2017[47]). There have been recent proposals to extend compulsory schooling in Romania to include the final two years of upper secondary and the first two years of pre-school education by 2020. This would translate to 15 years of compulsory education, longer than any other European country (the EU average for years of compulsory education is 10.5 years) (European Commission/EACEA/Eurydice, 2018[48]).

While extending compulsory education to include all of upper secondary education could help improve retention after grade 10, it will also be important to consider changes to curriculum and national exams. For example, there is currently no national exam or assessment that measures student learning at the end of compulsory education, which is a logical point in which countries measure learning outcomes. In fact, the World Bank-funded Romania Secondary Education Project (ROSE Project) has a mandate to develop a national assessment for grade 10 to fulfil this purpose; however, introducing a new assessment for grade 10 may not be necessary if compulsory education is extended.

Other measures countries have taken to address this challenge include creating a classroom environment that encourages students to achieve without generating an excessive fear of failure requires changes at class, school, societal and system levels. In particular, some systemic measures include:

- Mitigating the negative impact of selective exams. While high-stakes examinations are common in many countries, the absence of measures to mitigate their limitations in Romania has negative consequences for student learning, motivation and progression. In particular, the grade 8 exam does not reflect learning across the curriculum and is used to track students into different educational pathways (Kitchen et al., 2017 ${ }_{[1]}$ ). The grade 12 baccalaureate exam selects students for academic tertiary programmes and currently sets very different expectations for learning compared to the curriculum. Moreover, private tutoring is widespread for students preparing to take exams in Grades 8 and 12, increasing systemic inequalities by providing advantaged students with an advantage that their peers from lower income groups may not be able to access (Kitchen et al., 2017 ${ }_{[1]}$ ).

- Countries have mitigated the negative effects of selective exams by considering the teacher's advice (in addition to exam results) when selecting students into a particular education tracks rather than relying solely on exam results; this could help improve the equity and fairness of the grade 8 exam. The OECD Review on Evaluation and Assessment in Education: Romania also recommended revising the national examinations to align with the competency-based curriculum and allowing greater flexibility across learning pathways and certification so that students remain in education for longer and gain recognition for a wider range of skills.

- Reform the structure of schooling. Early tracking exacerbates differences in learning between students since it is more likely to place students from disadvantaged groups in lower or vocational tracks. The earlier the tracking occurs, the less easy it is for students to switch between tracks later, which can limit their future life chances and discourage them from staying 
in school (OECD, 2012[32]). Many countries are trying to address this challenge by improving the pathways and approaches to certification in secondary school. Another approach is to delay selection for one year by offering "bridge classes" to better assess a student's potential for the various education options (OECD, 2016[49]). Offering counselling services that provide students with psychological support and career guidance can also help students navigate the transition across education levels. Romania is yet to develop a strong, coherent reform agenda for addressing the negative effects of a highly selective and unequal secondary school system. Doing so could help encourage students to remain in education for longer.

- Improve the overall quality of VET. A strong VET system helps to ensure that all students have opportunities to achieve their full potential and engage students who may not be interested in academic subjects or have talents in other areas. Romania's National Strategy for Vocational Education includes measures to enhance the attractiveness of VET and its relevance for the labour market. These efforts are important since around $20 \%$ of students who were in Romanian VET programmes left school early as of 2010 (MNESR, 2015[31]).

- Rebalance curricula to engage students in learning. Relevant and engaging curricula can promote stimulating learning environments that encourage students to stay in school. Romania is currently implementing a major curriculum reform. As part of this effort, teachers should be encouraged to set high expectations for all students (see Policy Priority 1 ) and guidance should be developed on how to provide constructive feedback to build students' confidence and encourage them in their learning. Romania might also consider how well the structure and flexibility of the new curriculum fosters student engagement in learning at school. An example of how Finland has used curricular reforms to improve student drive and motivation is discussed in Box 5.

- Reduce school segregation. While a number of factors can impact the low achievement and attainment of certain student groups, in many countries school and classroom composition have an especially strong impact. Student allocation policies and transportation provisions often shape the distribution of students. In some cases, these policies contribute to the segregation of students from disadvantage neighbourhoods or families, compelling them to attend under-resourced and low-performing schools where they are more likely to experience poor quality teaching and learning environments (OECD, 2018[50] $)$. These conditions may lead students to disengage with learning. As such, many countries have taken steps to promote more diverse distributions of students, for example, by combining districts with different socio-demographic characteristics within a catchment area. Reducing segregation has the potential not only to benefit minority and other vulnerable students but also to improve student achievement in the aggregate (Hanushek, Kain and Rivkin, 2009 ${ }_{[51]}$ ). Reviewing how students are allocated to schools and implementing mechanisms that ensure more equal opportunities for all students are fundamental steps Romania could take to promote more inclusive education and keep students engaged in learning. 


\section{Box 5. Rebalancing curricula in Finland}

The Finnish Ministry of Education introduced Flexible Basic Education (JOPO) in 2008 to support individual learning needs and prevent early school leaving. Students in Grades 7 to 9 (13 to 15 years of age), who are identified as having low motivation, low levels of achievement and a need to study in a small group are eligible for enrolment in JOPO activities. These activities involve small group teaching, activity-based learning, individual guidance and different learning environments. For example, students may have opportunities for on-the-job learning, school camps and excursions.

Teachers (often with special education training) lead JOPO activities. Another professional (e.g. youth workers or instructors, teachers from non-formal learning programmes, or special needs assistants) supports them. The JOPO pedagogy emphasises inquiry-based and cooperative learning, as well as project learning. There is also an emphasis on skills such as time management, and social behaviour. The emphasis varies with each student group and the students' strengths and interests. Students participating in JOPO activities demonstrate improved motivation, school attendance, and rates of graduation.

Source: (School Education Gateway, n.d.[52]), "JOPO - Flexible Basic Education” School Education Gateway website, www.schooleducationgateway.eu/en/pub/resources/toolkitsforschools/detail.cfm?n=417 (accessed 27 March 2019).

\section{Leverage resources and support teacher quality in rural schools}

Early school leaving is primarily a rural issue in Romania (see Figure 4). While the rate of early school leavers in cities (at $4.2 \%$ ) is already well below the national and European targets, in Romanian towns and suburbs the rate is $14.9 \%$ and in rural areas it is nearly $25.4 \%$ (Eurostat, 2018[34]). The high rates of early school leaving in Romania's rural areas reflect the country's high rates of rural poverty. This highlights the multiple and cumulative factors that can affect students from disadvantaged backgrounds. Since nearly half of Romania's school-age children live in rural areas, these high rates of early school leaving also threaten to reinforce cycles of exclusion and deepen existing inequalities.

The Education Vulnerability Index, created by the World Bank to better understand the territorial distribution of key characteristics of the Romanian education system, shows that the most significant disparities among counties and between urban-rural areas relate to education quality and resilience. This refers to the "capacity of schools to perform given their local infrastructure and vulnerable students," (World Bank, forthcoming[53]). Counties with low performance are typically characterised by students living in remote, low-density places such as rural areas, indicating structural issues of poverty. Teacher characteristics and quality can also help explain some of the inequities. For example, PISA science results from 2015 reveal that part of the difference in achievement between students in urban and rural schools (students in urban schools tend to perform better) can be explained in part by a higher proportion of teachers who are more involved in student learning in urban areas (OECD, 2016 ${ }_{[5]}$; World Bank, forthcoming $\left.{ }_{[53]}\right)$. Teachers in urban areas are also more likely to have either a bachelor's or graduate degree and tend to implement more effective learning strategies in class (World Bank, forthcoming[53]). 


\section{Figure 4. Urban-rural divide of early school leavers in Romania (18-24 years)}

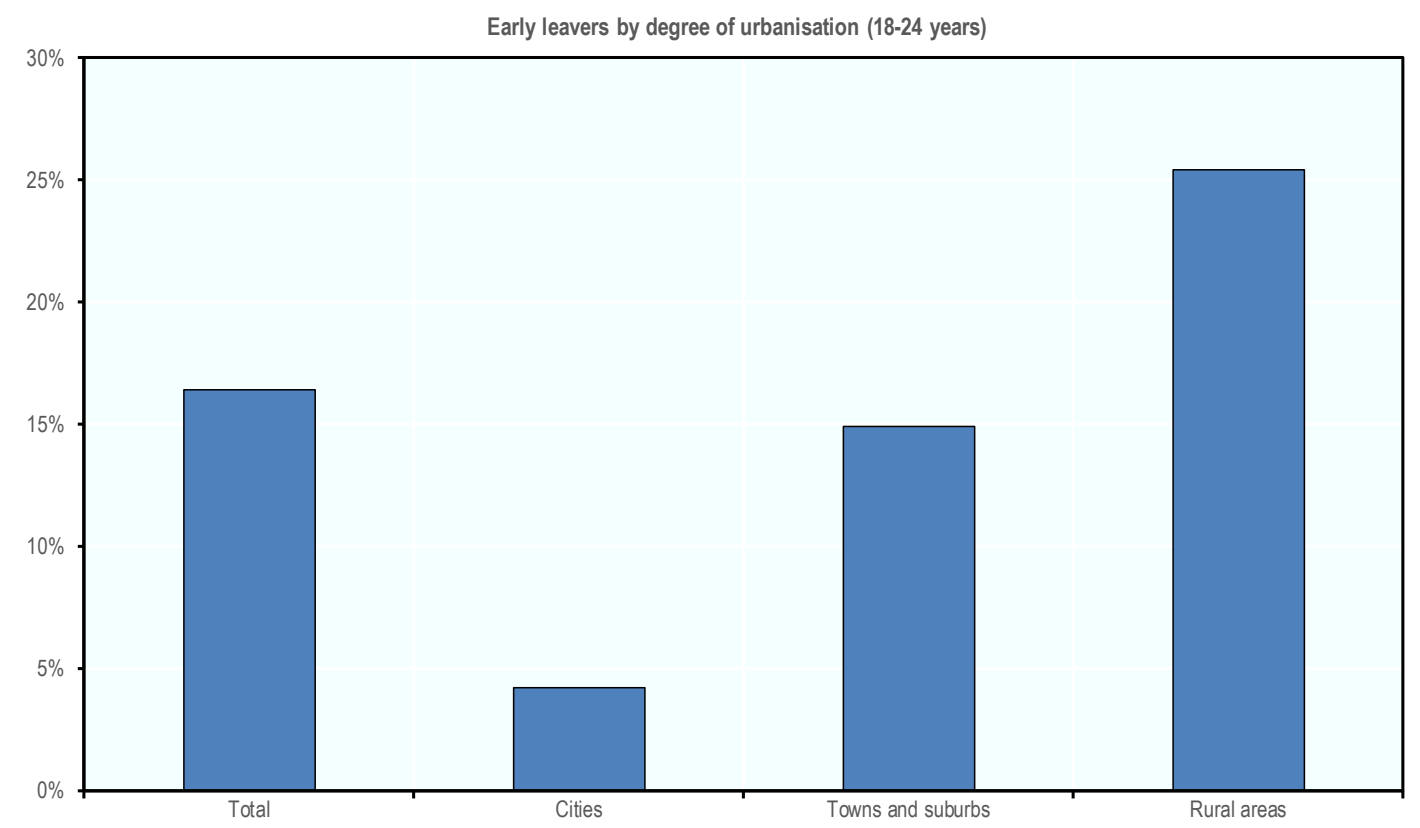

Source: (Eurostat, 2016[6]), Education and Training (database), http:/lec.europa.eu/eurostat/data/database (accessed 27 April 2019).

Students in rural areas may find their opportunities to continue in education limited because of resource constraints and fewer educational offers. For example, students in rural areas may have fewer study programmes to choose from compared to their peers in urban areas. Their schools may be far from home, difficult to access using public transportation and lack the infrastructure needed to provide high quality education. Currently, $60 \%$ of schools in Romania are underutilised (particularly in remote areas) and the infrastructure of rural schools is often inadequate, sometimes leaving parents to cover the costs of repairs, school supplies and sports equipment (European Commission, 2018[13]; Kitchen et al., 2017[1]). This exasperates inequalities and makes it difficult to establish the type of safe and modern learning environment that encourages students to stay in school. Furthermore, lack of additional financial resources for struggling schools often means that the budget and personnel allocations for rural schools to address early school leaving are insufficient (MNESR, 2015 $[31]$ ).

The Romanian government might consider developing specific policies that target rural schools, which often cater to under-served populations at risk of becoming early school leavers. This might include engaging parents in rural areas, such as the rural Roma community discussed in Box 4. It might also involve preparing and incentivising teachers to work in under-served areas or providing additional resources to support schools in tackling early school leaving and improving the quality of learning environments for their students. Portugal has used a territorial approach to help address early school leaving (see Box 6). 


\section{Box 6. Reducing early school leaving within geographical areas in Portugal}

Portugal has developed one of the most prominent and stable educational policies covering territorial intervention among OECD countries. Originally designed in 1996, with revisions in 2006 and 2012, Portugal's Priority Educational Intervention Areas (Territórios Educativos de Intervenção Prioritária - TEIP) aims to promote educational success and reduce early school leaving rates within geographical areas that have higher-than-average disadvantaged populations. Primarily funded by the European Social Fund, the TEIP programme allows schools (or school clusters grouped under centralised leadership) to apply for additional resources in order to develop specific projects and activities. To receive the additional resources, schools must prepare an application using specific criteria, which demonstrates their ability to design and implement evidence-informed plans. The Ministry of Education provides training and technical resources to schools to develop applications for the programme and allocations of resources mostly come in the form of extra human resources to execute a project, together with the financing of training related to the school project.

Between 2012 and 2016, the percentage of Portuguese school clusters covered by TEIP increased from $1 \%$ to $17 \%$ overall, or 137 school clusters, representing approximately $16 \%$ of students from primary to secondary level. School clusters evaluate progress annually through a formative first semester report and a final report. Cluster reports feed into the programme's evaluation of results at the national level (EC School Education Gateway, 2017). A recent synthesis of results suggests that dropout has reduced and results have improved in TEIP schools, but gaps remain between TEIP and non-TEIP schools (Dias, 2014). A fourth generation of the programme, currently in preparation.

Source: (OECD, 2018[54]), Education Policy Outlook 2018: Putting Student Learning at the Centre, Paris, OECD Publishing, https://doi.org/10.1787/9789264301528-en;

(Liebowitz et al., 2018[55]), Reviews of School Resources: Portugal 2018, https://doi.org/10.1787/9789264308411-en.

\section{Additional resources for schools and students in disadvantaged environments}

Equitable and effective resource allocation can help ensure that schools are able to support all students to stay in education. This might require giving more resources to disadvantaged students since their educational costs are often higher (OECD, 2012[32]). Educated Romania recognises the need for more equitable distribution of financial, material and human resources to schools in rural areas whose students face a high risk of early school leaving. Romania's current per-student funding formula adjusts for geographic location of the school, type of school and number of students per class (Fartuşnic et al., $2014_{[35]}$. However, many schools still report that funding remains insufficient, with significant variations in the level of school resources and how far they meet local needs (Kitchen et al., 2017 ${ }_{[1]}$ ).

Countries typically use a combination of two broad approaches when designing mechanisms to allocate funding in a way that recognises the different needs of schools and students (OECD, 2017[56]):

- The first is by including additional funding in the main allocation mechanisms for particular schools (e.g. by including weightings in the funding formula to systematically allocate additional resources to certain categories). Weights should align with national policy objectives and might include indicators based on individual student needs, the provision of a specialised curriculum or specific school characteristics. Importantly, these need to be accompanied by adequate accountability mechanisms to monitor the effective, efficient and equitable allocation of resources. The forthcoming OECD School Resource Review of Romania will examine the perstudent funding formula, which was introduced in 2011 in addition to other resource allocation challenges. Generally, Romania's low central spending on education means that current redistribution efforts (which weights school location, type of school and number of students per 
class), insufficiently address the needs of schools in regions with high levels of poverty (Fartuşnic et al., 2014[35]; Kitchen et al., 2017[1]).

- The second is by providing targeted resources in one or a series of different grants that are external to the main allocation mechanism. While OECD research has found that a multiplication of targeted programmes may risk leading to a lack of co-ordination, inefficiencies due to imposed restrictions on schools and greater administrative costs, they can also help steer and monitor the use of public resources to support greater equity at the school level (OECD, 2017[56]). Examples may include block, earmark or school-specific grants and/or lump-sum transfers that provide under-served schools and students with additional resources. Romania does not have any targeted programmes to channel additional resources to disadvantaged schools (Kitchen et al., 2017 ${ }_{[1]}$ ).

- Reducing the share of early school leavers cannot be achieved by improving the quality of education alone. It also requires alignment with other social policies to offer a complete set of measures that support students to stay in education. As such, targeted interventions at the individual level can support students in overcoming overcome potential barriers caused by their economic circumstances and stay in school (The Council of European Union, 2011 ${ }_{[57]}$ ). One way countries have done this is by providing conditional cash transfers that are subject to regular school attendance; however, individualised support might also be linked to social benefits that integrate social, financial, education and psychological support for young people in difficulties. Examples of integrated support might include providing services that directly benefit the child, such as educational support, meals, learning materials, clothes.

\section{Attracting teachers to work in disadvantaged areas}

Attracting experienced teachers and school leaders to work in disadvantaged rural areas is a challenge in many countries, including Romania. While increasing the salaries of teachers working in priority areas is often proposed as a means to attract teachers to these areas, evidence on the effectiveness of this incentive is mixed (OECD, 2018[58]). Romania already offers teachers working in rural areas a top-up but this has not been effective. This is partly because of the more difficult working conditions teachers in rural areas face, the need to commute and the reality in rural areas, teachers may not be able to supplement their incomes with private tutoring because of the higher levels of poverty (World Bank, forthcoming[53]). Instead, Romania might consider raising teaching standards to provide better incentives and working conditions to attract more experienced and qualified teachers to teach in rural areas (see policy brief on the teaching profession). For example, teachers may also benefit from mentoring and professional development opportunities that directly relates to the difficult contexts they work in and allows them to develop the skills needed to understand and address the diverse needs of their students.

Indirectly, such support can also modify teacher preferences. Teachers typically enjoy helping children develop and making a contribution to society, and have no reason to shy away from the challenges of teaching disadvantaged students. However, teachers are also more likely to want to work in disadvantaged schools if they feel they have support from principals, can collaborate with colleagues, and are provided with adequate resources to deal with the problems they face. School leaders who support and empower teachers can not only attract more and better-qualified teachers to work in disadvantaged schools, they also have a positive impact on the school climate more generally (see policy brief on professional management and leadership in education). Student behaviour is indeed better in schools whose principals are perceived as transformational leaders (OECD, 2018).

\section{Effective implementation and capacity development}

Romania has introduced several initiatives in recent years to tackle early school leaving. These include improving the attractiveness and relevance of the VET system, adopting a national strategy on early school leaving and drawing on a World Bank funding and technical assistance to improve upper secondary retention and the transition to tertiary education. While these initiatives focus on an important challenge 
facing Romania's education system, they do not appear to connect with each other or form part of a systemic policy for secondary education reform. Preventing early school leaving in Romania will require a coherent strategy to address the different dimensions of this challenge.

As is the case for strategies to address low-functional literacy in Romania, wider structural reforms - which are beyond the scope of this policy brief - will also be needed to reduce early school leaving. These include sufficient funding for disadvantaged areas and efforts to address school segregation and to raise the quality of all schools. As well as the individual measures highlighted above, Romania could consider the following:

- Invest in developing and expanding initial teacher education and continuous professional development offers so that teachers feel more prepared to work with disadvantaged and vulnerable students (see policy brief on the teaching profession). This might involve developing competencies to recognise and support individual students by designing remedial action plans for them.

- Develop pilot programmes in schools or areas with high dropout rates using some of the measures listed above. The Motivated Teachers in Disadvantaged Schools and School for All initiatives, which are being implemented with support from the European Social Fund, could serve as pilots. Such efforts should be reviewed and evaluated before scaling up to higher levels. 


\section{Policy priority 3. Developing support measures to help early school leavers return to school}

There are a number of reasons why an individual might leave school before completing of the level of education in which they were enrolled, or wish to enter an education programme or occupation for which they are not yet qualified (UNESCO-UIS, 2011 ${ }_{[59])}$ ). "Second chance" education programmes specifically target these individuals by offering a means for early school leavers to return to education. The Romanian Ministry of National Education and Scientific Research started piloting second chance education in 2001 by helping youth aged 14-24 to complete their lower secondary education (MNESR, 2015 [31]). Since then, Romania's second chance programmes have extended to cover primary education and to support at-risk groups, especially the country's Roma population.

While second chance education has the potential to help early school leavers, the distribution of programmes is uneven across the country and does not fully meet current demand (ibid). For example, $78 \%$ of participants in Romanian second chance courses (that are funded by the European Social Fund) live in urban areas, compared to only $22 \%$ in rural areas (MNESR, 2018[60]). Moreover, the European Commission has reported that participation in adult learning in Romania is quite low and second chance programmes are not tailored for adult learners (European Commission, 2015[61] $)$. Importantly, there have been no in-depth evaluations to determine how effective and efficient Romania's second chance programmes are in helping reintegrate individuals into the education system. Aware of these challenges, Educated Romania asked for support on:

- how to develop support measures that can help the early school leavers to return to school and cover the educational gaps they have.

\section{Potential impact}

Second chance education provides a way for early school leavers to return to school to complete their studies and obtain a formal qualification. Those who earn certificates will have opportunities to improve their skills and participate in tertiary education. This can improve their opportunities for employment, lifetime earnings and can help them adapt to jobs in more advanced sectors, such as automotive, machinery and electronic equipment (World Bank, 2018[62]). Moreover, since children's learning outcomes are strongly associated with the education level of the parents, participation in second chance education may also have an intergenerational impact. These effects are particularly strong where inequality is high (OECD, 2018[63]).

\section{International evidence and experiences}

Across countries, individuals with low levels of education are less likely to participate in opportunities for further learning. Some individuals may have had negative experiences at school, reducing the likelihood that they will want to return to education. Others may face a number of barriers that limit their ability to participate in further learning, including conflicting work schedules, lack of access to programmes due to transportation difficulties, conflicts with child care, and so on (OECD, 2008 $[64])$. A lack of awareness about 
opportunities, as well as the benefits associated with continued learning, may also contribute to low levels of participation in these programmes (Simona S. and Lustrea, 2017[65]).

Many programmes deliver second chance education in ways to help overcome these burdens. For example, programmes may offer courses outside of normal study hours or part-time, through distance or blended learning, and draw from more hands-on, tailored pedagogies to engage the interests of learners (CEDEFOP, 2018[66]). In developing support measures to help early school leavers return to education, Romania could draw on European research that has identified several common elements important for programme success (see Box 7).

\section{Box 7. Important elements of successful second chance programmes in Europe}

European research has identified several common elements important for programme success, including:

- Outreach in the local community to reach and engage youth who have left school. Teachers/local service providers can build relationships of trust with young people that can lead to enrolment in a programme and regular attendance.

- School cultures where learners are treated as "equals" and the atmosphere is open and characterised by mutual respect between teachers and learners.

- Multi-professional teams that can provide social and healthcare support.

- Student-centred approaches - Individualised learning, with prior learning and work experience taken into account.

- Positive links with employers to reinforce image that second chance education is a respectable pathway to certification and employment.

- Smaller class sizes, flexible organisation of work, modularisation of courses, distance learning, learning outside the classroom (e.g. place-based programmes).

Source: (CEDEFOP, 2018[66]), VET toolkit for tackling early school leaving: Second chance measures, www.cedefop.europa.eu/en/toolkits/vet-toolkit-tackling-early-leaving/intervene/intervention-approaches/second-chance-measures.

\section{Flexible alternatives to mainstream education}

By default, second chance programmes provide an alternative to mainstream education. As such, these programmes should adopt alternative approaches to meet the needs of learners who were not successful in the mainstream system. This can mean offering flexible arrangements, such as evening, weekend or part-time courses, removing barriers to access by waving entry and prior learning requirements or offering more hands-on learning opportunities (CEDEFOP, 2018[66]). Being flexible might also mean accepting that learners may need to miss classes, leave a course for some time, or to change classes and times of attendance (NRDC, 2008[67]). While it is important for providers to be flexible, they can also try to keep in contact with learners to update them on changes in provision, reconnect them with courses, or learn more about their reasons for leaving (Porter, Cuban and Comings, 2005[68]).

\section{Collaboration within the education system}

Some second chance education programmes offer individuals a chance to acquire a formal, recognised qualification that they did not attain through mainstream schooling. Others aim to support young people in the process of returning to formal learning or moving into employment. Despite the variety in purpose, all programmes need to fit into a flexible education system that enables young people to move forward with their learning and across different fields at the same level. Evidence from the European Centre for the Development of Vocational Training suggest various ways to do this: 
- Ensure that second chance programmes are formally accredited.

- Offer clear pathways that allow students to move within and across areas of education. This can allow students to return to mainstream education (especially for younger children), pursue higher levels of education and advance in their careers. Providing open, permeable pathways can also help reassure students that they are not restricted to their original choice since they can pursue programmes that better meets their interest and needs.

- Avoid repetition of learning, which can be demotivating for young people. This might involve recognising prior learning or allowing credit transfers. Breaking learning into manageable blocks can facilitate these processes. For example, modular assessments can give individuals a sense of achievement on a shorter time scale and help fill learning gaps without requiring students to repeat a full course (CEDEFOP, 2018[66]).

Close relationships between providers of mainstream and alternative education can help identify and direct students who have left school early (or are at risk of doing so) towards alternative options before students completely disengage with education.

\section{Promote positive attitudes towards second chance education}

In addition to flexible approaches, a key dimension of alternative education is having a positive learning environment that is friendly, free from stigmatisation and based on mutual respect (CEDEFOP, 2018[66]). This can help young people who may have struggled with or been excluded from mainstream education to develop a sense of belonging and confidence in their abilities. Teachers, parents and other professionals who are involved in both mainstream and alternative education programmes have a role to play in changing the negative preconceptions about these programmes and the students who participate in them. Positive links between employers and alternative education programmes can also reinforce the credibility of second chance programmes as a reputable pathway towards educational achievement and/or employment (ibid). The Second Chance School in the Champagne-Ardenne region of France (l'École de la Deuxième Chance) is one example of effective cooperation between education providers and employers (Box 8).

\section{Box 8. Second Chance School in Champagne-Ardenne, France}

The Second Chance School (École de la Deuxième Chance) in Champagne-Ardenne, France targets youth between 17 and 26 years of age and who are not in education, employment or training (NEET). The Second Chance School requires all participants to combine study and work experience in order to achieve the qualification they are seeking. During the first weeks of entry into the School, companies from a range of professional sectors intervene in classes so that students can discover trades and explore different tracks. Progressively, students develop a professional project and do an internship in a relevant company.

The Second Chance School student body in 2017 consisted of:

- $24 \%$ rural inhabitants

- $7 \%$ of non-European nationality

- $2 \%$ individuals with disabilities

- $64 \%$ who had no professional experience prior to entering the school.

At the end of that year, $23 \%$ of graduates had a permanent work contract, $64 \%$ had a temporary work contract, $1 \%$ created their own enterprise, and $12 \%$ had other types of work contract when they left the programme.

Source: (E2C, n.d.[69]), École de la 2e Chance, web site, www.e2C-alfor.frl (accessed April 2019). 


\section{Effective implementation and capacity development}

To support effective implementation and capacity development for second chance education programmes, Romania will need to make second chance learning a national priority and allocate sufficient resources to support this effort. There also needs to be strong political will to develop a coherent approach and build partnerships with social services and employers to leverage existing resources to support these programmes. For example, establishing a dedicated department or institution to serve as an umbrella for second chance and adult education can help raise the status of these programmes as reputable alternatives towards educational achievement and/or employment (CEDEFOP, 2018[66]). This will also require raising awareness among youth and adults about opportunities to earn certification and supporting learner persistence. Programmes need to accommodate learners. For example, Romania will need to address practical barriers (lack of time, lack of access to childcare, etc.). Most importantly, individuals who have had to drop out of education for various reasons need support to drop in.

\section{Sequencing reforms to improve educational equity}

All students stand to gain from equitable and high quality education. This is achieved when all individuals can reach at least a minimum level of skills (inclusion), but also when personal or social circumstances, such as socio-economic background, gender, ethnic origin or family background, do not hinder achieving education potential (fairness) (OECD, 2012[32]). Figure 5 sets out a suggested sequence for introduction of reforms to improve educational equity in Romania:

- Phase 1: Establish a long-term vision and plan for educational equity in Romania that identifies priorities. Some countries do this by promoting equity through general strategy and others introduce policies that target specific groups of students, such as those with special education needs or Roma backgrounds (OECD, 2018[54]). Initiatives should be aligned with resource requirements (human and financial) and include a clear role for actors outside of the education system, such as social service providers.

- Phase 2: Set out actions. These might include actions to increase student mobility between tracks, efforts to attract and retain qualified and experienced teachers (see policy brief on the teaching profession); developing training offers and tools to support teachers who work with disadvantaged and vulnerable students; increasing support for students within mainstream schools; tailoring second chance education programmes to meet the needs of adult learners; intervening early (see policy brief on early childhood education and care); and developing measures to channel resources to the most disadvantaged regions and schools.

- Phase 3: Deepen the strategy(ies) over time and monitor student learning and other student outcomes.

- Phase 4: Adjust programmes based on evaluation data and needs. 
Figure 5. Sequence of reforms to improve educational equity in Romania

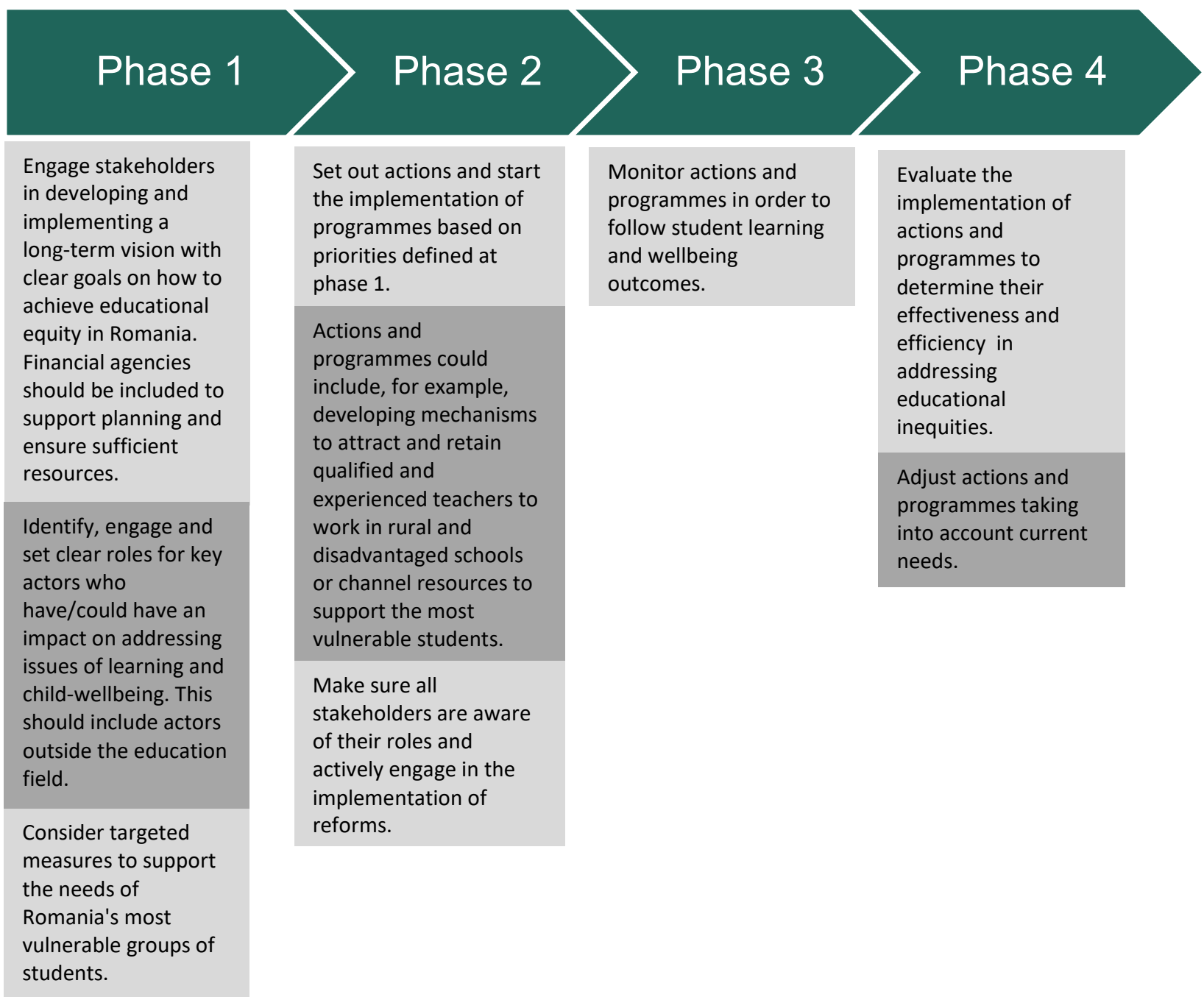

\section{References}

Agasisti et al. (2018), Academic resilience: What schools and countries do to help disadvantaged students succeed in PISA, OECD Publishing, Paris, http://dx.doi.org/10.1787/e22490ac-en.

Ahtiainen, R. et al. (2012), Tehostettua ja erityistä tukea tarvitsevien oppilaiden opetuksen kehittäminen 2007-2011. Kehittävän arvioinnin loppuraportti, opetus- ja kulttuuriministeriö.

Black, P. and D. Wiliam (1998), "Assessment in Education: Principles, Policy and Practice”, Policy \& Practice, Vol. 5/1, pp. 7-74, http://dx.doi.org/10.1080/0969595980050102.

Black, R. (2007), Crossing the Bridge Overcoming entrenched disadvantage through student-centred learning, Education Foundation Australia, the R.E. Ross Trust, https://files.eric.ed.gov/fulltext/ED501899.pdf (accessed on 14 March 2019).

CEDEFOP (2018), VET toolkit for tackling early school leaving: Second chance measures,

http://www.cedefop.europa.eu/en/toolkits/vet-toolkit-tackling-early-leaving/intervene/interventionapproaches/second-chance-measures (accessed on 31 January 2019). 
Cohen, J. et al. (2009), "School Climate: Research, Policy, Practice, and Teacher Education", Teachers College Record, Vol. 111/1, pp. 180-213, http://www.ijvs.org/files/Publications/School-Climate.pdf (accessed on 5 November 2018).

Dumont, H., D. Istance and F. Benavides (2010), How can the learning sciences inform the design of 21 st century learning environments? The Nature of Learning Using Research to Inspire Practice Practitioner, OECD Publishing, Paris.

Dweck, C. (2006), Mindset: The New Psychology of Success, Random House.

E2C (n.d.), École de la 2e Chance, website, http://www.e2c-alfor.fr/ (accessed on 1 May 2019).

Eder, D. (1981), "Ability Grouping as a Self-Fulfilling Prophecy: A Micro-Analysis of Teacher-Student Interaction", Sociology of Education, Vol. 54/3, pp. 151-162, http://dx.doi.org/doi:10.2307/2112327.

EEF (2018), Teaching and Learning Toolkit, Education Endowment Foundation, https://educationendowmentfoundation.org.uk/evidence-summaries/teaching-learning-toolkit/ (accessed on 14 March 2019).

Elinet (n.d.), European Literacy Policy Network website, http://, http://www.eli-net.eu/goodpractice/examples-of-good-practice/detail/project/strathclyde-literacy-clinic.

European Commission (2019), Country Report Romania 2019 Including an In-Depth Review on the prevention and correction of macroeconomic imbalances, European Commission, Brussels, https://ec.europa.eu/info/sites/info/files/file import/2019-european-semester-country-reportromania en.pdf.

European Commission (2018), Education and Training Monitor 2018, Publications Office at the European Union, Luxembourg, http://dx.doi.org/10.2766/707224.

European Commission (2015), An in-depth analysis of adult learning policies and their effectiveness in Europe, Publications Office of the European Union.

European Commission (2011), "Tackling early school leaving. A key contribution ot the Europe 2020 Agenda", European Commission Communication [COM(2011)18], https://eurlex.europa.eu/LexUriServ/LexUriServ.do?uri=COM:2011:0018:FIN:EN:PDF (accessed on 15 March 2019).

European Commission/EACEA/Eurydice (2018), Compulsory Education in Europe - 2018/19, http://dx.doi.org/10.2797/20126.

European Commission/EACEA/Eurydice (2017), Compulsory Education in Europe 2017/18, http://dx.doi.org/10.2797/579346.

European Education Council (2003), EU Education Ministers in the Council in 2003 (Council conclusions on "Reference levels of European Average Performance in Education and Training (Benchmarks)".

European Union (2018), Smarter, greener, more inclusive? Indicators to support the Europe 2020 Strategy, Publications Office of the European Union, Luxembourg, http://dx.doi.org/10.2785/80156.

Eurostat (2019), Main tables - Eurostat, Education and training data, European Comission, https://ec.europa.eu/eurostat/web/education-and-training/data/main-tables (accessed on 18 March 2019).

Eurostat (2018), Education and Training (database), http://ec.europa.eu/eurostat/web/educationandtraining/data/database.

Eurostat (2016), Education and Training (database), http://ec.europa.eu/eurostat/web/educationandtraining/data/database (accessed on 5 March 2019). 
Fartuşnic, C. et al. (2014), School Participation in Upper Secondary Education: A challenge for the current policies in Romania, UNICEF, Bucharest, https://www.unicef.org/romania/Participarea la edu inv sec en site.pdf (accessed on 17 March 2019).

Flecha, R. and M. Soler (2013), "Turning difficulties into possibilities: Engaging Roma families and students in school through dialogic learning", Cambridge Journal of Education, Vol. 43/4, pp. 451-465, http://dx.doi.org/10.1080/0305764X.2013.819068.

Goodenow, C. (1993), "Classroom beloning among early adolesscent students relationships to motivation and achievement”, Th eJournal of Early Adolescence, Vol. 13/1, pp. 21-43.

Hanushek, E., J. Kain and S. Rivkin (2009), "New Evidence about Brown v. Board of Education: The Complex Effects of School Racial Composition on Achievement", Journal of Labor Economics, Vol. 27/3, pp. 349-383, http://dx.doi.org/10.1086/600386.

Horga, Irina; Jigău, Mihaela; Apostu, Otilia (2017), La scoală, o privire asupra participării la educatie folosind analiza pe cohortă [At school, a look at participation in education using cohort analysis], UNICEF, Bucharest, http://www.ise.ro/wp-content/uploads/2017/11/Studiu-Cohorta.pdf (accessed on 17 March 2019).

Kitchen, $\mathrm{H}$. et al. (2017), OECD Reviews of Evaluation and Assessment in Education Romania, https://www.oecd-ilibrary.org/docserver/9789264274051en.pdf?expires $=1552554948 \&$ id=id\&accname=ocid84004878\&checksum=166E163127BB5398342C9EF 258746355 (accessed on 14 March 2019).

Liebowitz, D. et al. (2018), OECD Reviews of School Resources: Portugal 2018, OECD Reviews of School Resources, OECD Publishing, Paris, https://dx.doi.org/10.1787/9789264308411-en.

Ministère de l'Éducation Nationale (2018), Évaluations Diagnostiques en CP [Diagnostic Evaluation in CP], http://eduscol.education.fr/cid119562/evaluation-diagnostique-en-cp.html. (accessed on 1 May 2019).

MNESR (2018), Report on monitoring implementation of sectoral strategies for education and training in 2017, Ministry of National Education and Scientific Research.

MNESR (2016), Ordinul MENCS nr. 6161/2016 - aprobarea Metodologiei şi criteriilor privind acordarea gradaţiei de merit personalului didactic din învăţământul preuniversitar de stat în sesiunea 2017 [Order of the Minister 6161/2016 approving the methodology for and criteria for granting merit gradation of teaching staff in state pre-session 2017], Ministry of National Education and Scientific Research, http://legeaz.net/monitorul-oficial-21-2017/omencs-6161-2016-metodologie-criteriiacordare- gradatiemerit-invatamant-preuniversitar, (accessed on 9 February 2016).

MNESR (2015), Strategy to Reduce Early School Leaving 2015-2020, Ministry of National Education and Scientific Research, http://pubdocs.worldbank.org/en/698181496304535110/Strategy-to-Reduce-EarlySchool-Leaving-mare.pdf.

NRDC (2008), "Supporting Skills for Life Learnders to Stick with it! A guide for managers, practitioners and learners”, National Research and Development Centre for Adult Literacy and Numeracy, Vol. London.

Nusche, D. (2009), "What Works in Migrant Education? A Review of Evidence and Policy Options", No. 22, OECD, Paris, http://www.oecd.org/edu/workingpapers.

OECD (2018), Education Policy Outlook 2018: Putting Student Learning at the Centre, OECD Publishing, Paris, https://dx.doi.org/10.1787/9789264301528-en.

OECD (2018), Responsive School Systems: Connecting Facilities, Sectors and Programmes for Student Success, OECD Reviews of School Resources, OECD Publishing, Paris, https://dx.doi.org/10.1787/9789264306707-en.

OECD (2018), The Productivity-Inclusiveness Nexus, OECD Publishing, Paris, https://dx.doi.org/10.1787/9789264292932-en. 
OECD (2017), PISA 2015 Results (Volume III): Students' Well-Being, PISA, OECD Publishing, Paris, https://dx.doi.org/10.1787/9789264273856-en.

OECD (2017), The Funding of School Education: Connecting Resources and Learning, OECD Reviews of School Resources, OECD Publishing, Paris, https://dx.doi.org/10.1787/9789264276147-en.

OECD (2016), Low-Performing Students: Why They Fall Behind and How to Help Them Succeed, PISA, OECD Publishing, Paris, https://www.oecd-ilibrary.org/docserver/9789264250246en.pdf?expires=1552464360\&id=id\&accname=ocid84004878\&checksum=3BEE58D1AC76E87BED667 E90836ABF85 (accessed on 13 March 2019).

OECD (2016), "Making sense of early tracking in the Netherlands", in Netherlands 2016: Foundations for the Future, OECD Publishing, Paris, https://dx.doi.org/10.1787/9789264257658-6-en.

OECD (2016), PISA 2015 Results (Volume I): Excellence and Equity in Education, PISA, OECD Publishing, Paris, https://dx.doi.org/10.1787/9789264266490-en.

OECD (2016), PISA 2015 Results (Volume V): Collaborative Problem Solving, PISA, OECD Publishing, Paris, https://dx.doi.org/10.1787/9789264285521-en.

OECD (2013), PISA 2012 Results: Ready to Learn (Volume III): Students' Engagement, Drive and SelfBeliefs, PISA, OECD Publishing, Paris, https://dx.doi.org/10.1787/9789264201170-en.

OECD (2013), Synergies for Better Learning: An International Perspective on Evaluation and Assessment, OECD Reviews of Evaluation and Assessment in Education, OECD Publishing, Paris, https://dx.doi.org/10.1787/9789264190658-en.

OECD (2012), Equity and Quality in Education: Supporting Disadvantaged Students and Schools, OECD Publishing, Paris, https://dx.doi.org/10.1787/9789264130852-en.

OECD (2010), PISA 2009 Results: What Students Know and Can Do: Student Performance in Reading, Mathematics and Science (Volume I), PISA, OECD Publishing, Paris, https://dx.doi.org/10.1787/9789264091450-en.

OECD (2008), Teaching, Learning and Assessment for Adults: Improving Low Foundation Skills, OECD Publishing.

OECD (2007), PISA 2006: Science Competencies for Tomorrow's World: Volume 1: Analysis, OECD Publishing Paris, https://doi.org/10.1787/9789264040014.

OECD (2005), Formative Assessment: Improving Learning in Secondary Classrooms, OECD Publishing, http://www.oecd.org/education/ceri/35661078.pdf.

Paris (ed.) (2018), Effective Teacher Policies: Insights from PISA, OECD Publishing.

Popović, G. (ed.) (2017), Participation Rates in Lifelong Learning: Why is Romania not so Successful?, Sense Publishers.

Porter, K., S. Cuban and J. Comings (2005), "One day I will make it: A study of adult persistence in librayr literacy programs”, New York: Manpower Demonstration Research Corporation.

Rist, R. (2015), "Student Social Class and Teacher Expectations: The Self-Fulfilling Prophecy in Ghetto Education", Harvard Educational Review, Vol. 40/3, pp. 411-451, http://dx.doi.org/10.17763/haer.70.3.1k0624l6102u2725.

Rus, C. and M. Zatreanu (2009), Education of Roma children in Europe: Guide for Roma school mediators/assistants, Council of Europe Publishing, https://www.schooleducationgateway.eu/files/esl/downloads/07 Guide for Roma School Mediators.pdf (accessed on 17 March 2019). 
School Education Gateway (2016), European Toolkit for School, https://www.schooleducationgateway.eu/en/pub/resources/toolkitsforschools/latest resources.htm.

School Education Gateway (n.d.), JOPO - Flexible Basic Education, http://www.schooleducationgateway.eu/en/pub/resources/toolkitsforschools/detail.cfm?n=417 (accessed on 1 May 2019).

Schuller, T. (2017), "What are the wider benefits of learning across the life course?", Government Office for Science, United Kingdom,

https://assets.publishing.service.gov.uk/government/uploads/system/uploads/attachment data/file/63583 7/Skills and lifelong learning - the benefits of adult learning - schuller - final.pdf.

The Council of European Union (2011), Council Recommendation of 28 June 2011 on policies to reduce early school leaving (Text with EEA relevance) 2011/C 191/01, Official Journal of the European Union, https://eur-lex.europa.eu/legal-content/EN/TXT/HTML/?uri=CELEX:32011H0701(01)\&from=EN.

Thomson, J. (n.d.), The Strathclyde Literacy Clinic, Univeristy of Strathclyde Glasgow website, https://pureportal.strath.ac.uk/en/projects/the-strathclyde-literacy-clinic (accessed on 1 May 2019).

Thuneberg, H. et al. (2014), "Conceptual change in adopting the nationwide special education strategy in Finland", Journal of Educational Change, Vol. 15/1, pp. 37-56, http://dx.doi.org/10.1007/s10833-0139213-x.

UNESCO-UIS (2011), International Standard Classification of Education ISCED 2011, UNESCO Institute for Statistics, Quebec, http://www.uis.unesco.org (accessed on 21 March 2019).

UNICEF (2017), Improving Education Participation: Policy and Practice Pointers for Enrolling All Children and Adolescents in School and Preventing Dropout, UNICEF Series on Education Participation and Dropout Prevention-Volume 2, http://www.unicef.org/ceecis. (accessed on 7 January 2019).

West, A. (2007), "Poverty and Educational Achievement: Why do Children from Lower-Income Families Tend to do Less Well at School?", Benefits, Vol. 15/3, p. 283.

Wiliam, D. (2010), "The role of formative assessment in effective learning environments", in The Nature of Learning: Using Research to Inspire Practice, OECD Publishing, Paris, https://dx.doi.org/10.1787/9789264086487-8-en.

World Bank (2018), From Uneven Growth to Inclusive Development Romania's Path to Shared Prosperity, World Bank, Washington DC, http://documents.worldbank.org/curated/en/673121528867676119/pdf/127129-PUB-PUBLIC-pub-date6-6-18.pdf (accessed on 21 March 2019).

World Bank (forthcoming), Romania Public Finance Review: Enhancing the Efficiency of Public Spending in Pre-University Education, World Bank. 
This policy brief was undertaken by the OECD with funding from the European Union and implemented in cooperation with the Structural Reform Support Service to support the Educated Romania project.

This work is published under the responsibility of the Secretary-General of the OECD. The opinions expressed and arguments employed herein do not necessarily reflect the official views of OECD member countries.

This document, as well as any data and any map included herein, are without prejudice to the status of or sovereignty over any territory, to the delimitation of international frontiers and boundaries and to the name of any territory, city or area.

You can copy, download or print OECD content for your own use, and you can include excerpts from OECD publications, databases and multimedia products in your own documents, presentations, blogs, websites and teaching materials, provided that suitable acknowledgment of OECD as source and copyright owner is given. All requests for commercial use and translation rights should be submitted to rights@oecd.org. 